\title{
Effects of Resource Limitation on the Physical and Reproductive Condition of Sika Deer on Nakanoshima Island, Hokkaido
}

\author{
Koichi KAJI, Toru KOIZUMI \& Noriyuki OHTAISHI
}

Kaji K., Koizumi T. \& Ohtaishi N., 1988: Effects of resource limitation on the physical and reproductive condition of sika deer on Nakanoshima Island, Hokkaido. Acta theriol., 33, 13:187-208 [With 5 Tables, 8 Figs. \& Plate XV].

The physical and reproductive condition of introduced sika deer (Cervus nippon yesoensis Heude, 1884) on Nakanoshima Island $\left(5.2 \mathrm{~km}^{2}\right)$ were studied during a 5-year-period. The population density increased from 31.5 deer $/ \mathrm{km}^{2}$ in 1980 to $57.5 \mathrm{deer} / \mathrm{km}^{2}$ in the autumn of 1983 , and declined the following winter to 26.3 deer $/ \mathrm{km}^{2}$ due to both natural mortality $(22 \%)$ and removal $(32 \%)$. As the population increased, availability of summer and winter forages rapidly decreased. Deer had eliminated dwarf bamboo by 1983 , which was the most important forage in winter, and were forced to consume more bark and unpalatable plant species. In the winter of $1983-84$, in conjunction with a longer snow cover than usual, a mass mortality $(22 \%)$ from starvation was recorded. Although the body weights and skeletal size of island deer initially were almost the same as those of mainland deer, the 1984 animals of both sexes were smaller in body weight and chest girth than the 1982 animals. Sexual dimorphism in body weight and measurements (chest girth and hind foot length) became apparent only after 1.5 -years-old in 1982, and after 2.5-years-old in 1984. Skeletal growth (jaw length and skull length) gradually declined in immature age classes with a higher population density. Antler growth, associated with the decrease in body weight, also decreased. The ratio of fawn to one-year-old or older females in autumn declined drastically from $65 \%$ in 1980 to $7 \%$ in 1984. Resource limitation caused by high population density, and fluctuating climatic conditions are the main factors that determined both the size of the individual deer and the population.

[Department of Forestry, Faculty of Agriculture, Hokkaido University, Sapporo 060, Japan (KK); Forestry and Forest Products Research Institute, Kansai Branch, Hushimi-ku Kyoto 612, Japan (TK); Department of Anatomy, Faculty of Dental Medicine, Hokkaido University, Sapporo 060 , Japan (NO)]

\section{INTRODUCTION}

Over the last 10 years, the distribution range of sika deer (Cervus nippon yesoensis Heude, 1884) has extended from eastern to western Hokkaido, and presently occupies $60 \%$ of Hokkaido's total land area. Between the late 1960 's and 1980 's, the annual harvests reported by hunters increased from ca. 2000 animals to ca. 4000 animals. Although the actual number of deer harvested is not known due to the present management system, the above results suggest that the population increased remarkably in recent decades. Hence, research was planned in 
order to develop proper management methods for this species. Data on the physical and reproductive performance were collected as part of a study on the population dynamics of sika deer on an island.

Three sika deer, an adult male, a yearling female, and a pregnant female were introduced into Nakanoshima Island in the years 1957, 1958, and 1965, respectively, from the Hidaka district, which is located in the south-eastern part of Hokkaido. The population increased rapidly, with subsequent offects on vegetation. One of the objectives of the study was, therefore, to investigate how the physical and reproductive conditions of sika deer may be related to food resource limitation.

\section{STUDY AREA}

This study was carried out on Nakanoshima Island located in Lake Toya in the south-west part of Hokkaido from March 1980 to October 1984 (Fig. 1). There are two small adjacent islets, Manju and Benten-Kannon. These three islands, which have a total area of $5.2 \mathrm{~km}^{2}$, are the central crater hills of the caldera-lake, and lie $3 \mathrm{~km}$ away from the surrounding mainland. The elevation of the islands, ranges from 80 to $450 \mathrm{~m}$ above sea level. Nakanoshima Island is composed of three steep mountains and two small flat pastures on the central and southern parts of the island.

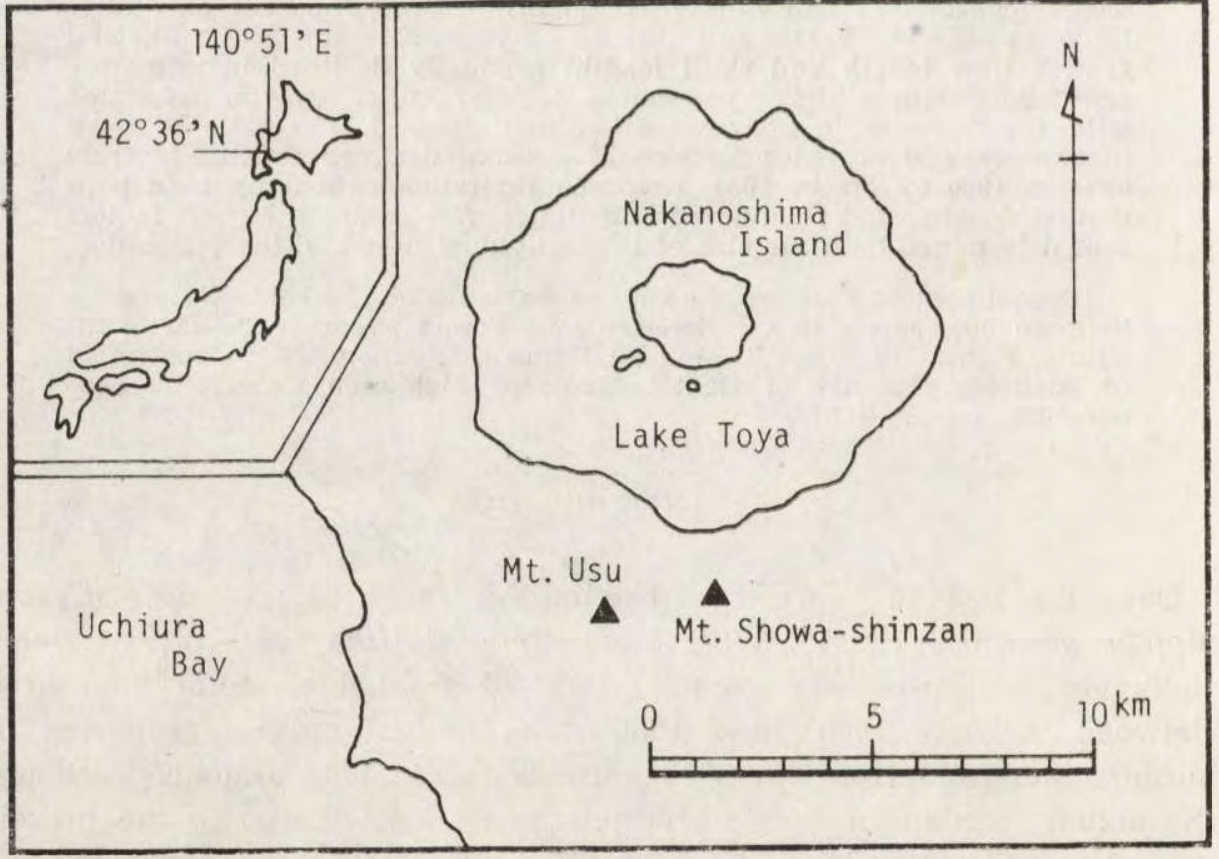

Fig. 1. Study area of Nakanoshima Island with the two adjacent islets in Lake Toya, Hokkaido, Japan. 
Snow covers the islands from December to mid-April. During the study, the maximum snow depth was observed in February (a mean of $48 \mathrm{~cm}$ ), and the lowest temperature was also recorded in February (a mean of $-2.1^{\circ} \mathrm{C}$ ) at the Toya Limnological Station, Hokkaido University, $4 \mathrm{~km}$ west of the island.

There are no predators and no hunting pressure on the island. The forest consists of deciduous broad-leaved trees, poor grasses and sedges. The dominant tree species on Nakanoshima Island originally were maple (Acer mono), lime (Tilia japonica), elm (Ulmus laciniata) and hydrangea (Hydrangea paniculata). The area also contains a small plantation of Sakhalin fir (Abies sachaliensis) and Japanese larch (Larix leptolepis). Major understory species were dwarf bamboo (Sasa senanensis and S. kurilensis) and plum-yew (Cephalotaxus harringtonia).

\section{MATERIAL AND METHODS}

\section{3,1. Count}

During 1980-1984 (excluding 1981), the counting of deer was carried out each winter using a driving-out method and a small outboard-motor boat. We divided the islands' area into four or five blocks. In each block drivers lined up along the edge of mountain or ridge, and moved across one block until they arrived at the lakefront. Deer, forced to move, were tallied by one or two observer(s) from a boat. Deer forced to pass through the line were recorded by drivers to avoid double-counting. Deer counts were completed in all blocks in two days by 16 people.

Because of the difficulties in counting deer in wooded areas, the actual numbers are higher than the counts suggest. In view of the fact that the counts during 1980-1983 were underestimated, corrected numbers were used as estimates of population density. The corrected population size for previous years was calculated from fawn/doe ratios in winter and known mortality based on the 1984 count. Although at least 5 animals dispersed from the island to the surrounding mainland during this study, the herd on the island was regarded to have been isolated, and immigration-emigration, if it occurred, could not influence the deer number.

Herd composition counts, obtaining the ratio of fawns to yearling and adult females, were made on two pastures between September and November, when the animals tended to be concentrated in those areas. This data was combined to make the autumn fawn/doe ratio.

\subsection{Availability of Food for Sika Deer}

The vegetation on the islands was studied with belt transects and meter-square quadrats. Sika deer in Hokkaido depend mainly on green forage during summer and autumn, but during the snowy winter months, the feeding habits change to browsing on dwarf bamboo and woody species or to bark peeling (Kaji, 1981). For summer forage, we surveyed the composition and height of plants. On Nakanoshima Island, the most important forage in winter was dwarf bamboo (Kaji et al., 1984), as in other areas of Hokkaido (Kaji, 1981), in Omote-Nikko, central Honshu (Maruyama et al., 1975; Takatsuki, 1983) and on Mt. Goyo, northern Honshu (Takatsuki, 1986). Therefore, we could expect the reduction of dwarf bamboo to afect the sika deer's nutrition in late winter. 
Quantitative evaluation of the effect of sika deer on dwarf bamboo was made by observing five sets containing two groups of meter-squared quadrats. Each group included two quadrats; one which suffered from deer grazing, and the other which was protected from grazing by a deer-proof fence constructed in 1981. The fence on Manju Islet was constructed in 1982. In 1981 a series of measurements of leaf volume was made at random in 28 grazed quadrats, and then also made both in protected and unprotected quadrats during 1982-1983. Samples of the leaves were weighed after being oven-dried at $70^{\circ} \mathrm{C}$.

The bark peeling survey was made at belt transects settled in wintering ranges during $1980-1983$. The belt transects $(n=5)$ were $10 \mathrm{~m}$ in width and from $120 \mathrm{~m}$ to $300 \mathrm{~m}$ in length. The total area was $8700 \mathrm{~m}^{2}$. Bark biomass (B), and consumed bark (C), were obtained in each unit area by measuring the trees' diameter at breast height (d.b.h.), and the total area of bark which deer had peeled to $150 \mathrm{~cm}$ above-ground; the mean of maximum height of bark peeling $(n=222)$. The mean dry weight of bark $\left(0.082 \mathrm{~g} / \mathrm{cm}^{2}\right)$ was obtained from four tree species. Bark biomass $(B)$ is calculated with the following formula: $B=($ d.b.h. $\times 3.14 \times 150-C) \times$ $\times 0.082$.

\subsection{External and Skeletal Measurements}

Deer were captured by a corral trap, or from a boat when the deer were driven into the lake. We captured four sika deer (two males and two females) between March and Novęmber in 1981, $55(23,32)$ in March 1982, and $105(45,60)$ in February and April 1984. The captive animals in 1984 were kept for about one month in an enclosure and fed artificially. Body measurements were made immediately after the capture in 1982, but the 1984 measurements were made in April and May, one month after the deer had been captured. Since there were no significant differences in body weight and measurements (chest girth and hind foot length) between the deer measured in April and May of 1984, the data from both months were combined.

Captive deer were weighed to the nearest $0.1 \mathrm{~kg}$ with a spring scale and on a platform scale. The following measurements were taken on each individual: chest girth (measured immediately behind the axilla), hind foot length (from the tip of the hoof to the calcanes), and antler length (the straight-line distance from the casting burr to the tip). All measurements were made to the nearest $0.1 \mathrm{~cm}$ with a flexible steel tape measure. All antler protuberances over $2.5 \mathrm{~cm}$ long were counted as the number of points. If one antler of the pair was missing, the measurements of the one antler was not used in comparisons involving deer with two antlers. In 1982 a pair of colored-numbered plastic ear tags were attached on both ears to record age-related antler points in males, and postpartum productivity in females.

Carcasses of 98 deer (54 males and 44 females) were obtained for measurements, either during organized intensive searches or incidentally between $1980-1984$. The samples included some animals which died of unnatural cause $(n=14)$. The remains varied from skeletons to fresh bodies. Almost all carcasses found in the spring were relatively fresh, but a few dry skeletons, which were intact, were assumed to be the remains from deer that died the previous year. Two fawns, which either died before winter or were born in autumn, were not included. The skulls (without the lower jaw) and antlers of male mainland deer shot in eastern Hokkaido during the 1979 hunting season (15 November through 15 January) 
$(n=135)$ were measured and compared with those of the island deer. The following measurements were taken: jaw length (from the posterior margin of the ramus to the exterior edge of the alveolus of the first incisor), and total length of the skull (from prosthion to acrocranion). Skull measurements were made to the nearest $0.1 \mathrm{~mm}$ with a caliper. The antlers of the captive deer were measured using the same method.

\subsection{Aging}

The age of captive deer was estimated by the eruption and wear of mandibular dentition, using criteria established for sika deer by Ohtaishi (1980), and Koike \& Ohtaishi (1985). Captive deer older than 4.5-years-old were combined into the 4.5 age class. In determining age of the skull, tooth eruption patterns were used with deer up to 2.5-years-old. Older animals were aged by annulations in the decalcified section of the first incisor $\left(I_{1}\right)$. In cases where the front teeth were missing, age was determined by the first molar $\left(\mathbf{M}_{1}\right)$, according to Ohtaishi (1980).

\subsection{Fat Reserves}

The fat reserves of sika deer which died in winter or early spring from natural or accidental causes, were measured using two indexes: the kidney fat index (KFI), and the femur marrow fat contents (FMF). The KFI was obtained by expressing the weight of fats around the kidney as a percentage of the kidney weight, as described by Riney (1955). The FMF was obtained by calculating the percentage of water (W) in a 2 or $3 \mathrm{~g}$ marrow sample from the central part of the femur through the dehydration method of Neiland (1970). The FMF was calculated with the following formula: FMF $=92-0.994 \times(\mathrm{W})$, which was established for sika by Maruyama (1985).

\section{RESULTS}

\subsection{Population Density and Trends}

After the introduction of three animals in 1957, 1958, and 1965, the sika deer population grew to 102 by 1980 , and to between 190 and 198 animals by 1982 (Kaji et al., 1984). The number of deer counted was 234 in 1983, and 273 in 1984 (Table 1). Of the winter censuses between 1980 -1984 (no data is available for 1981), the 1984 census was thought to be best because 81 animals were captured in an enclosure set up for their removal, and over 100 animals came to a feeder (set up in December 1983) where the census was carried out. Since an accurate census was carried out in 1984, counts of the previous years were based on this 1984 census.

Estimated deer density in winter increased from 31.5 deer $/ \mathrm{km}^{2}$ in 1980 to 52.5 deer $/ \mathrm{km}^{2}$ in 1984 (Table 1). The number of deer found dead was $3,5,8$ and 17 animals for $1980,1981,1982$ and 1983, respectively. During the March 1984 census, 26 animals were found dead, and an 
additional 41 animals were found dead after the count. Most of them were found soon after death. The mortality, a total of 67 , in the winter of 1983-84 was quite high. In addition, a total of 95 animals were removed for relocation in April and May. Thus the population density peaked at 57.5 deer $/ \mathrm{km}^{2}$ (299 animals) in the autumn of 1983; and declined to 26.3 deer $/ \mathrm{km}^{2}$ (137 animals) prior to the breeding season of 1984 (Table 1).

Table 1

\begin{tabular}{|c|c|c|}
\hline \multicolumn{3}{|c|}{$\begin{array}{l}\text { Number of deer counted, and estimated } \\
\text { population size and density calculated } \\
\text { from recruitment and known mortality } \\
\text { based on the } 1984 \text { census. }\end{array}$} \\
\hline Month & $\begin{array}{c}\mathrm{N} \\
\text { Observed }\end{array}$ & $\begin{array}{l}\mathrm{N}\left(\mathrm{N} / \mathrm{km}^{2}\right) \\
\text { Estimated }\end{array}$ \\
\hline March 1980 & 102 & 164 (31.5) \\
\hline March 1981 & $\mathrm{NC}$ a & $199(38.3)$ \\
\hline December 1981 & 190 & \\
\hline February 1982 & 198 & $233(44.8)$ \\
\hline March 1983 & 234 & $260(50.0)$ \\
\hline March 1984 & 273 & $273(52.5)$ \\
\hline May 1984 & & $232(44.6)^{\mathrm{b}}$ \\
\hline June 1984 & & $137(26.3)^{c}$ \\
\hline
\end{tabular}

\subsection{Availability of Food for Sika Deer}

In 1981, the pasture at the central part of Nakanoshima Island (open pasture) consisted of forbs, grasses, and tall plants over $100 \mathrm{~cm}$ in height, such as ragwort (Senecio cannabifolius), eulalia (Miscanthus sinensis) and angelica (Angelica ursina). Grasses exceeded $30 \mathrm{~cm}$ in height, and there was no obvious effect of grazing on the vegetation in the open pasture (Plate XV). From 1982, a large number of deer concentrated in the open pasture during the summer and autumn (Fig. 2), and the vegetation was greatly affected by the heavy graze of sika deer. All tall plants disappeared except ragwort, which was not grazed by deer (Plate XV). The number of deer using the pasture was the greatest in 1983, when half of the total population concentrated at an average density of 20 animals/ha from June to October (Fig. 2).

In winter, deer concentrated on sunny slopes covered with dwarf bamboo. There were three species of dwarf bamboo on the islands. $S$. senanensis and a small amount of $S$. kurilensis had covered a quarter of Nakanoshima Island; and S. nipponica had covered all of Manju Islet. 


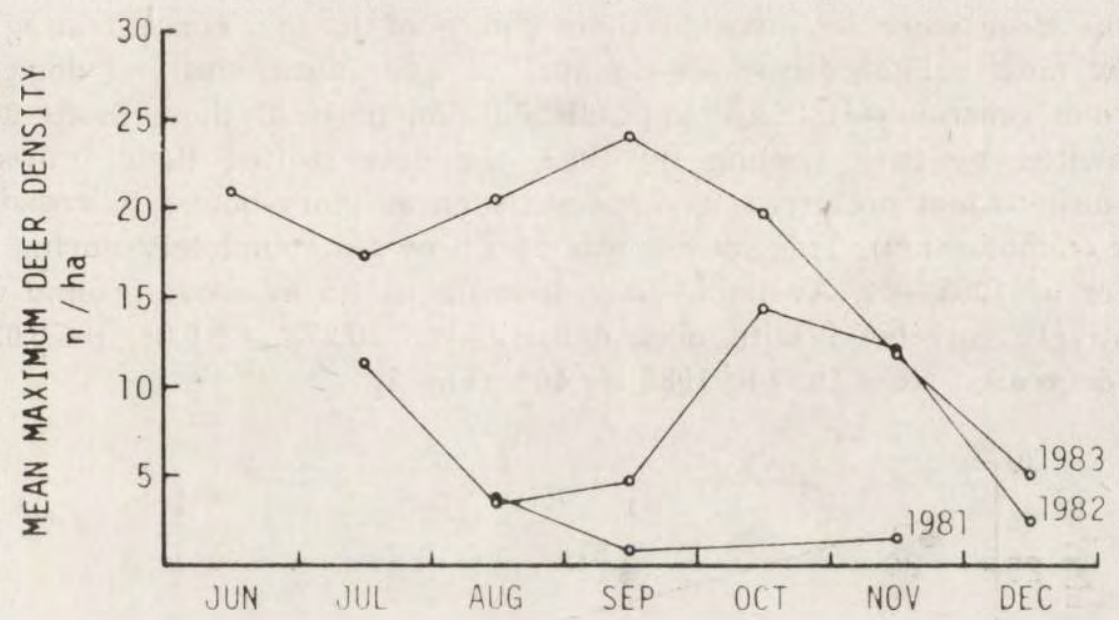

Fig. 2. Mean maximum density of deer which used the open pasture (6.8 ha) from 1981 to 1983.

On Benten-Kannon Islet, however, S. senanensis was scarce because of heavy grazing by a pair of sheep which died before 1980 (Kaji et al., 1984). The leaf weight of the dwarf bamboo increased in the fenced plots, while it decreased in the unfenced plots in 1982, and was eliminated by 1983, except on Manju Islet, where complete elimination occurred the following year (Table 2). The mean percentages of the contents of the rumen (in volume) taken from eight sika deer, which were killed during a capture attempt in March 1982, were bark $44.6 \pm 30.4 \%$, fallen leaves $21.3 \pm 17 \%$, dwarf bamboos $8.8 \pm 13.4 \%$, scouring rush (Equisetum hyemale) $3.1 \pm 2.6 \%$, and others (unidentified) $25.3 \pm 28.9 \%$ (Koyama, unpublished). The items other than dwarf bamboo and bark are not common foods of sika deer.

Table 2

Leaf weight of dwarf bamboo (gram dry weight per $\mathrm{m}^{2}$ ) in 1981 , given as the mean value $\pm \operatorname{SD}(n)$, and changes in the weight from 1981 to 1983 in five fenced and ten unfenced study plots.

\begin{tabular}{|c|c|c|c|c|c|}
\hline & \multirow{2}{*}{$\frac{1981}{\text { Unprotected }}$} & \multicolumn{2}{|c|}{1982} & \multicolumn{2}{|c|}{1983} \\
\hline & & Enclosed & Unprotected & Enclosed & Unprotected \\
\hline \multirow[t]{2}{*}{ Nakanoshima Is. } & $29.1 \pm 9.3$ & 48.2 & 0.3 & & 0 \\
\hline & $4.1 \pm 3.3$ & 14.2 & 2.9 & & 0 \\
\hline \multirow{2}{*}{ Benten-Kannon Is. } & $2.0(1)$ & 13.6 & 0.6 & 21.3 & 0 \\
\hline & $0.3(1)$ & 12.6 & 1.4 & 22.5 & 0 \\
\hline Manju Is. ${ }^{a}$ & 34.1 (1) & 41.8 & 50.9 & 70.3 & 21.4 \\
\hline
\end{tabular}

a The plot on Manju Is, was enclosed in April 1982. 
Sika deer were selective in their choice of forage, concentrating on a few most palatable tree species such as hydrangea, elm and dogwood (Cornus controversa) (Kaji, unpublished). As most of these foods were exhausted by bark peeling by 1983 , the deer shifted their browsing pressure to less preferred tree species such as glory-bower (Clerondendron trichotomum). This species was also browsed completely during the winter of 1983-84. Available bark biomass to $1.5 \mathrm{~m}$ above-ground was negatively correlated with deer density $(r=-0.978, t=6.61, p<0.025)$, and decreased from 1980 to 1983 by $40 \%$ (Fig. 3).

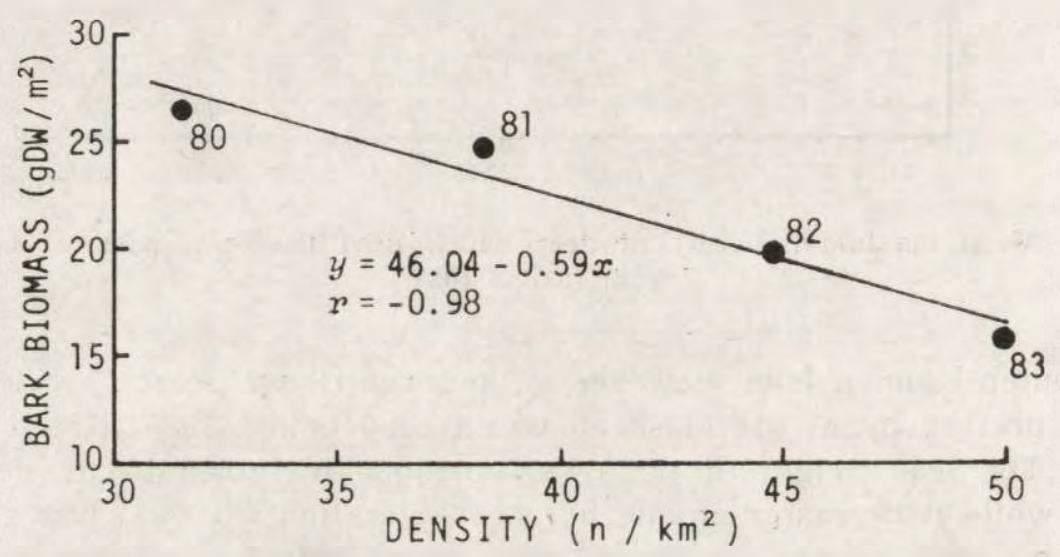

Fig. 3. Available bark biomass plotted against deer density from 1980 to 1983. Numbers beside each point show the year.

\subsection{Body Size and Skeletal Growth}

In 1981, although only four deer were captured to measure body size on Nakanoshima Island, the deer were in good condition. Their body weights, measured in March (two fawns), September and November (two adults) were: $31 \mathrm{~kg}$ for the male fawn, $40 \mathrm{~kg}$ for the female fawn, $115 \mathrm{~kg}$ for the adult male, and $78 \mathrm{~kg}$ for the adult female. They were similar to those of mainland deer, as reported by Kudo \& Ohtaishi (1977). However body weight, chest girth, and hind foot length of the island deer between 1982 and 1984 changed quite drastically (Fig. 4). Excluding the age classes of 2.5-year-olds and 3.5-year-olds because of a small sample size in 1982, data from the two years were compared, every measurement categorized for each age class for males and females.

The mean body weight of the 1984 animals was significantly lighter than that of the 1982 animals in every age class: $(p<0.01$ for male fawns, $p<0.001$ for female fawns, $p<0.001$ for yearling males, $p<0.001$ for older males, and $p<0.05$ for older females). The 1984 males and females 
were 24-34 percent and 16-29 percent lighter than the animals checked in 1982 , respectively. The mean percentage of weight loss of yearlings and older males was approximately twice that of females. In fawns, however, the magnitude of changes was similar between the sexes. In all of the three age classes (fawns, 1.5 , and $45+$ ) of males and females, chest girth was significantly $(p<0.02 j)$ smaller in 1984 than in 1982. Fawns of both sexes $(p<0.005)$ and yearling males $(p<0.01)$ had significantly shorter hind feet in 1984 than in 1982.
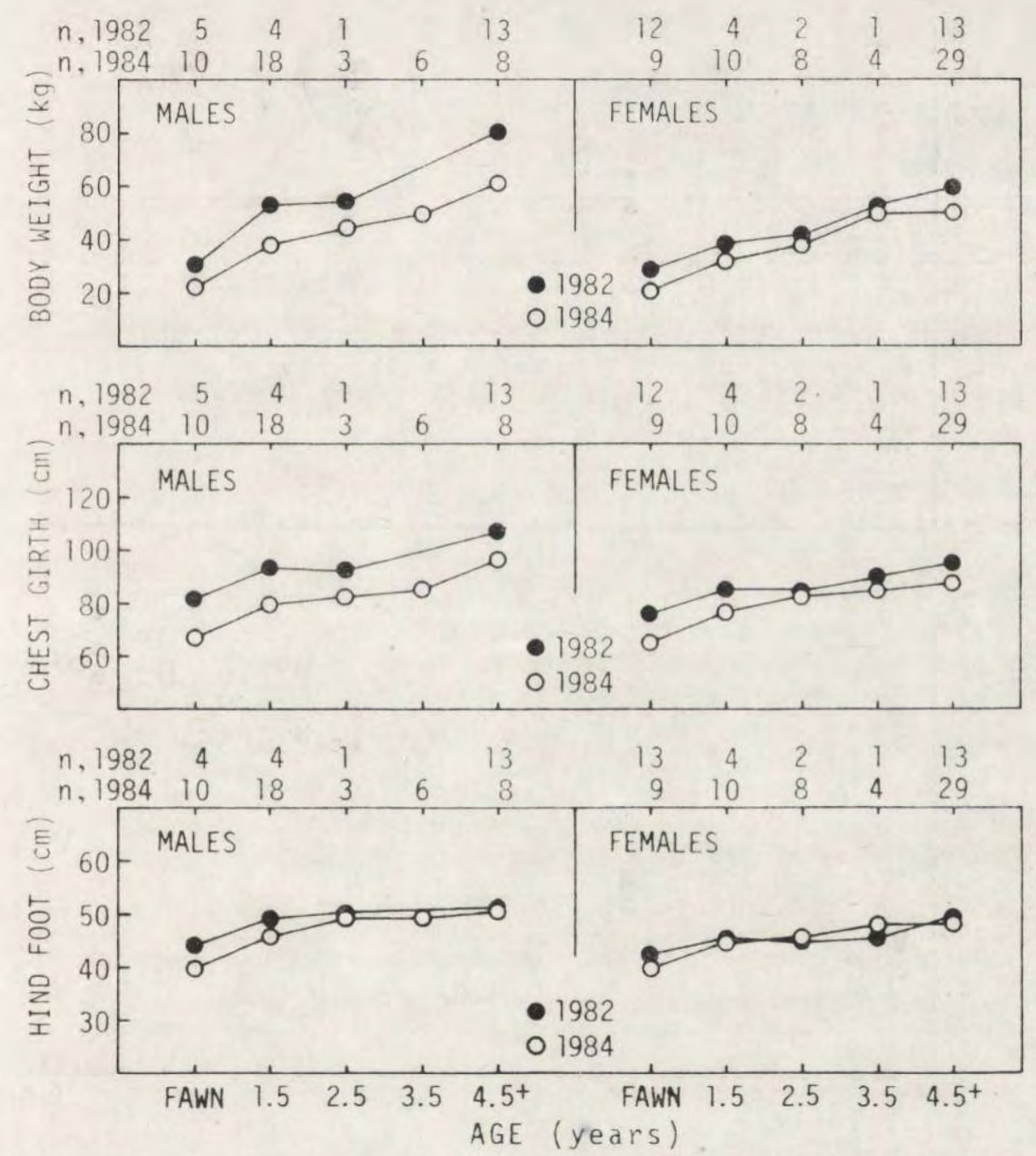

Fig. 4. Body weight, chest girth, hind foot length of male and female sika deer in March 1982 and April-May 1984. 
In 1982 , males were significantly $(p<0.05)$ larger than females of the same age in all measurements for yearlings and 4.5-year-old and older individuals. In 1984, however, the only significant difference between males and females was in relation to body weight $(p<0.025)$ and hind foot length $(p<0.005)$ of 2.5 -year-old individuals and in all the measurements $(p<0.005)$ of 4.5 -year-old and older animals. There were no significant differences in the measurements of yearlings and 3.5-year-olds, and the chest girth for 2.5-year-olds did not change substantially.

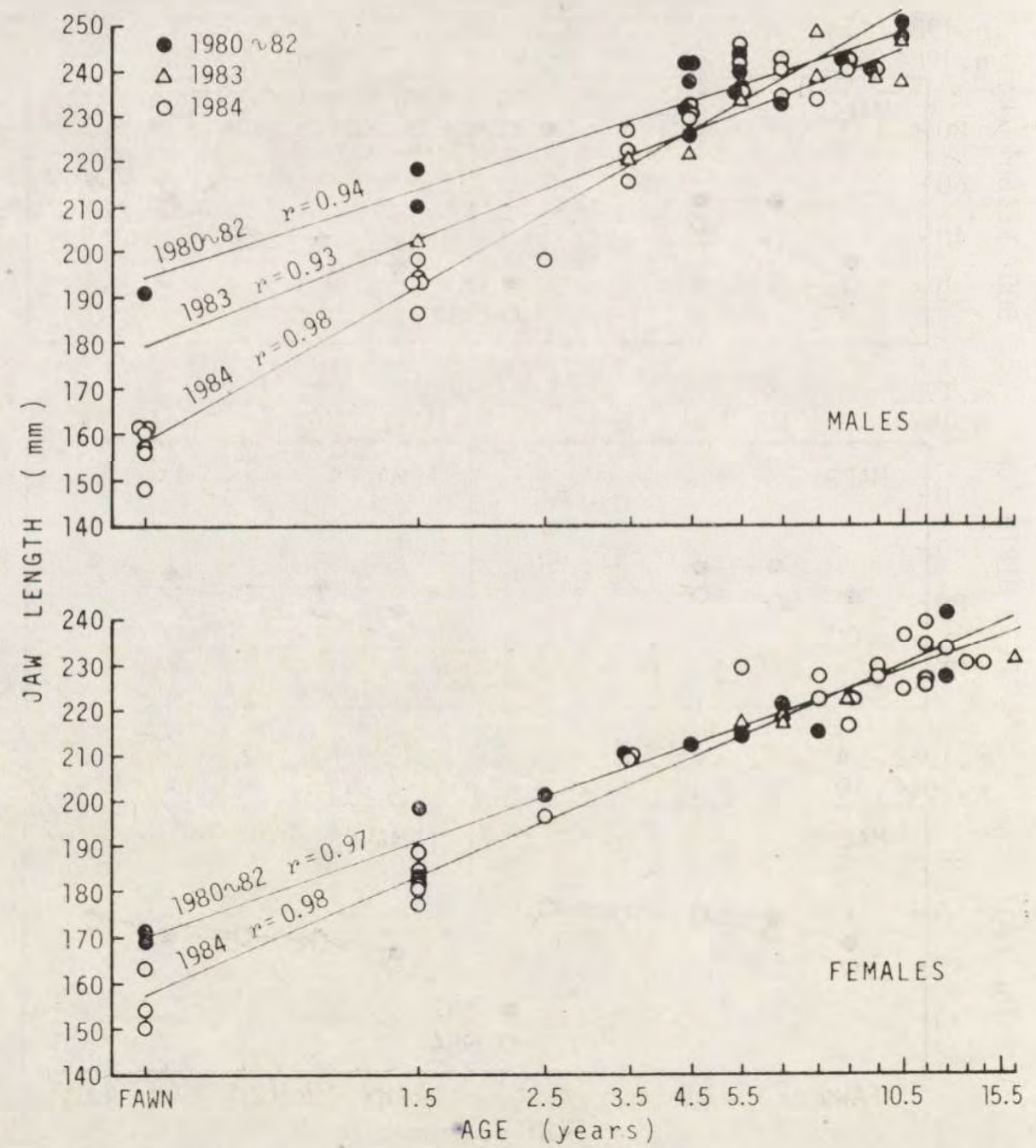

Fig. 5. Jaw length plotted against the logarithm of age of male and female sika deer in $1980-82,1983$, and 1984 . The $1980-82$ samples included some jaws from animals which died before 1980 . 
Since the body size was correlated to the differences in habitat conditions and population densities, the differences in growth rates can be expected. Fig. 5 shows the regression of jaw length versus the age of sika deer. The significant differences in slope for males in $1980-1982$, 1983 , and $1984(F=22.48$, d.f. $=2,48, p<0.01)$ and for females in 1980 1982 and $1984(F=5.49$, d.f. $=1,35, p<0.05)$ were expected, and showed that the mean size of the young in different years differred considerably. The regressions of the total length of the skull versus the age of males one year or older show a similar gradient to those of jaw length (Fig. 6). However, they did not differ significantly in slope $(F=1.7$, d.f. $=2,40$, $\mathrm{p}>0.25)$ but were very different in elevation $(F=13.63$, d.f. $=2,42$, $p<0.001)$.

The regression line of the mean skull size versus age for mainland deer is also shown in Fig. 6. When the skull size of male island deer, collected in 1980 - 1982, were compared to those of mainland deer, they did not differ significantly either in slope $(F=3.64$, d.f. $=1,21, p>0.05)$

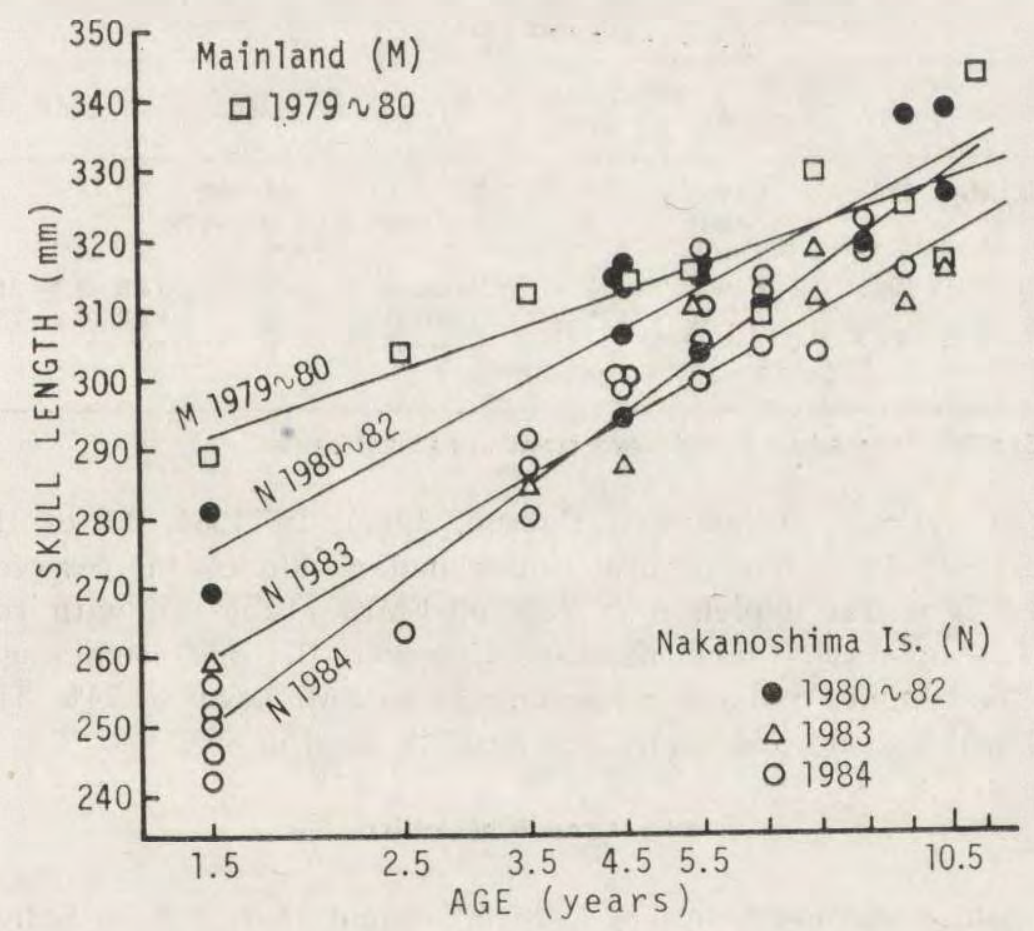

Fig. 6. Skull length plotted against the logarithm of age of male sika deer from Nakanoshima Island in 1980-82, 1983, and 1984, and from the mainland herd. The 1980-82 samples on Nakanoshima Island included some skulls from animals which died before 1980 . 
or in elevation $(F=1.39$, d.f. $=1,21, p>0.05)$. This indicates that the skull size, like the body weight, was similar to those of mainland deer initially, and the difference in development was most pronounced in the immature classes in an environment with resource limitation.

\subsection{Fat Reserves}

In the mid-winter of $1981-82$, we collected kidneys and the surrounding fat from 8 animals which were killed during a capture attempt. These animals showed high KFI (Table 3 ), but only 1 adult showed a depleted kidney fat reserve $(<30$ of KFI) at a level of 18. Maruyama (1985) reported that in sika deer, KFI decreases to an index of 30 with high and consistent FMF $(>80 \%)$, but with further fat mobilization, FMF declines sharply. This relationship was also found in white-tailed

Table 3

Kidney fat index (KFI) and percentage of marrow fat (FMF) in sika deer. given as the mean value and ranges on Nakanoshima Island, in 1982 and 1984 .

\begin{tabular}{llllll}
\hline Year \& Month & Age & $\begin{array}{c}\text { Sample } \\
\text { size }\end{array}$ & $\begin{array}{c}\text { Cause of } \\
\text { death }\end{array}$ & KFI & FMF \\
\hline Feb.-Mar. 1982 & & Fawn & 2 & Accident $76(66-86)$ & \\
& Adult & 6 & Accident $63.8(18-139)$ & \\
& Total & 8 & & 66.9 & $14.3(3.3-21)$ \\
Feb.-Mar. 1984 & Fawn & 3 & Natural & $12.8(0.1-73.5)$ \\
& Adult & 11 & Natural & 69 \\
& Adult & 1 & Accident & 13.1 \\
\hline
\end{tabular}

a Excludes the adult found dead from unnatural causes.

deer (Odocoileus virginianus) (Ranson, 1965). In 1984, 13 of the 14 animals that died from natural causes had no kidney fat reserves and suffered from fat depletion ( $<25 \%$ of FMF) (Table 3 ), with reddish, gelatinous or watery bone marrow. However, the one remaining adult animal had higher marrow percentage at an FMF level of $74 \%$. The one animal which died accidentally had an FMF level of $69 \%$.

\subsection{Growth of Antlers}

On male island deer, antlers were taken and studied from individuals that died from natural or unnatural causes during this study, and from deer captured in 1982 and 1984. Observations of marked males of known age $(n=14)$ were included in the data concerning antler points. This data was divided into two periods; $1980-1983$ and 1984. 
Mean antler length and antler points of male island deer and those of mainland deer are given in Table 4. The first set of antlers of a yearling male mainland deer was a simple unbranched spike averaging about $26 \mathrm{~cm}$ long. Occasionally spikes had simple prongs 2 or $3 \mathrm{~cm}$ in length coming off the main beam. Out of 15 yearling males, $5(33 \%)$ had forked antlers or additional tines. Ohtaishi (1976) also found that all yearling sika deer males in Nara park, Japan $\left(n_{a}=45\right.$ sets $)$ had spikes. The second antlers, averaging $46 \mathrm{~cm}$ in length, had a mean of 3.8 points/ antler. Of the 35 sets of 2.5-year-olds, the majority ( $80 \%)$ had 4-points although one had two. The third set of antlers, averaging $55 \mathrm{~cm}$ in length, had the typical 4-points on each antler. The antlers of 4.5-yearuld and older males had large beams with 4-points/antler.

Table 4

Age-specific antler lengths and antler points of male sika deer, given as the mean value $\pm \mathrm{SD}(n)$, from Nakanoshima Island and from the mainland herd.

\begin{tabular}{|c|c|c|c|}
\hline \multirow[t]{2}{*}{$\begin{array}{c}\text { Age } \\
\text { (years) }\end{array}$} & \multicolumn{2}{|c|}{ Nakanoshima Island } & \multirow{2}{*}{$\begin{array}{c}\text { Mainland } \\
1979-80\end{array}$} \\
\hline & $1980-83$ & 1984 & \\
\hline \multicolumn{4}{|c|}{ Antler length $(\mathrm{mm})$} \\
\hline 1.5 & $204.4 \pm 30.7$ & $107.4 \pm 41,7$ & $264.7 \pm 55.2$ \\
\hline 2.5 & & $245.5 \pm 30.0$ & $460.3 \pm 63.7$ (35) \\
\hline 3.5 & & $284.0 \pm 28.1$ & $548.1 \pm 63.2(31)$ \\
\hline$\geqslant 4.5$ & $531.7 \pm 71.9$ & $436.1 \pm 83.1$ & $615.9 \pm 65.5$ \\
\hline \multicolumn{4}{|c|}{ Antler points $(\mathrm{N})$} \\
\hline 1.5 & $1.0(6)$ & $0.5 \pm 0.5$ & $1.0(15)$ \\
\hline 2.5 & $3.5(2)$ & $2.1 \pm 0.9$ & $3.8 \pm 0.5$ \\
\hline 3.5 & 3.0 (1) & $2.5 \pm 0.7 \quad(7)$ & $4.0(31)$ \\
\hline$\geqslant 4.5$ & $3.8 \pm 0.4(26)$ & $3.3 \pm 0.4(21)$ & $4.0 \pm 0.1(50)$ \\
\hline
\end{tabular}

Antler size increased until the age of seven. Very old males with reduced antler points have been reported in Nara park by Ohtaishi (1976). Similar cases were usually found in the males on Nakanoshima Island, but only one $(2 \%)$ of 50 mainland adult males ( $\geqslant 4$-years-old).

Antlers of adult male island deer $(\geqslant 4$-years-old) collected during $1980-1983$ were significantly smaller both in length $(p<0.01)$ and in the number of points $(p<0.025)$ compared to those of mainland deer. Although there was no statistical difference in the antler length of yearling males, probably due to small sample size, the antler length was also smaller than those of mainland deer.

The changes in antler characteristics of island deer also occurred in the two periods. The antler length and antler points of yearling males and adult males were significantly $(p<0.005)$ smaller in samples collected in 1984 than those collected in 1980-1983. In 1984 , only $8(36.4 \%)$ of 
22 yearling males had spikes of over $8 \mathrm{~cm}$ in length, two gave no indication of the pedicel sites on the frontal bones, and the remaining 12 $(54.5 \%)$ yearlings had "button" antlers or fur covered knobs.

The antler length of captive yearlings and adults ( $\geqslant 4.5$-years-old) studied in 1982 and 1984 was closely related to body weight $(r=0.906$, $t=8.581, \quad p<0.001 ; r=0.827, t=4.156, p<0.005$, respectively), and was shorter weight decreased (Fig. 7). Miura et al. (1980) also found that antler length was closely related to body weight among adult male sika deer $(r=0.92, n=94, p<0.001)$ in his study at Nara Park.

\subsection{Female Reproduction}

In 1982, both 1.5-year-old $(n=1)$ and 2.5-year-old $(n=1)$ females, killed during capture in March, were pregnant. The observation of marked females of known age during 1982 and 1984, however, showed that none of the 112.5 year-old females had fawns (Table 5).

The ratio of fawns to one year old and older females, which were

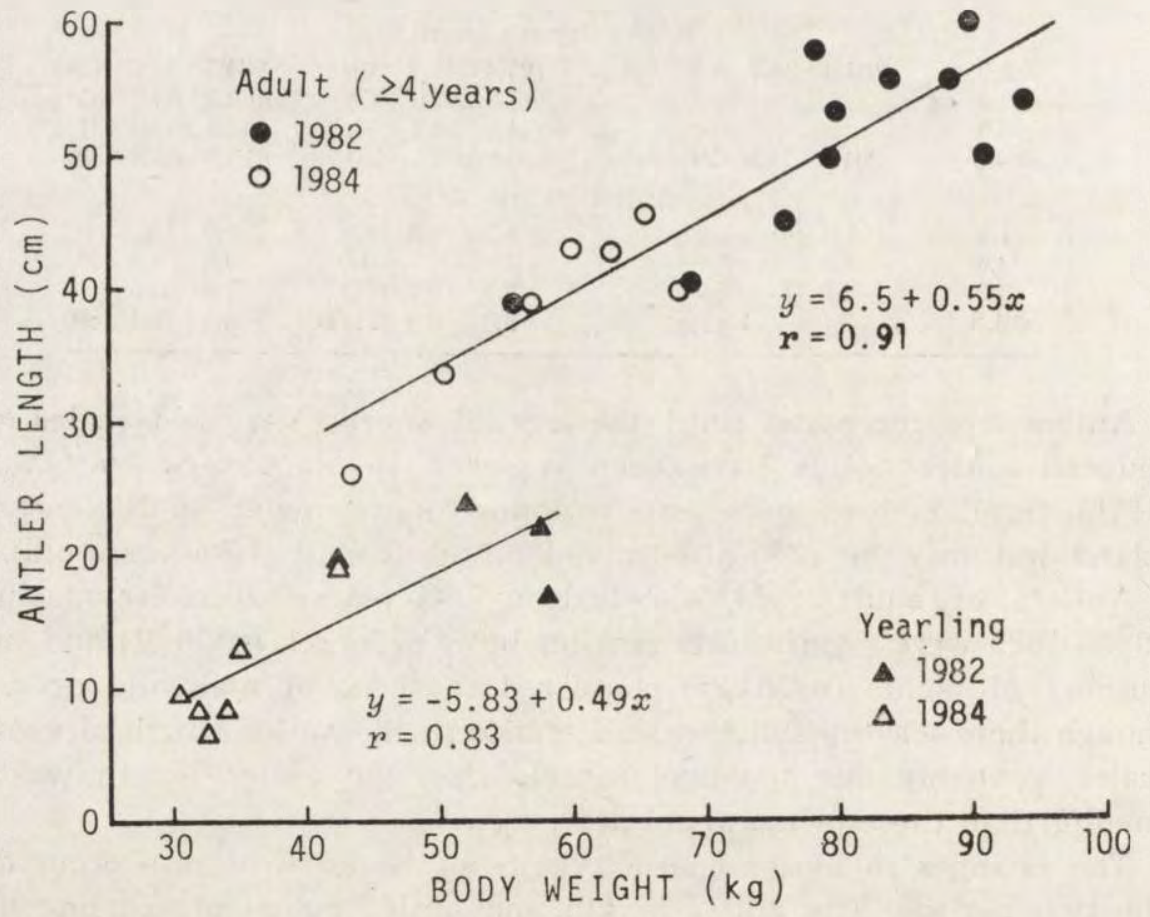

Fig. 7. Antler length plotted against body weight in yearling and 4-year-olds or older males. Excluded antlers below $6 \mathrm{~cm}$ in length. 
observed on the two pastures in autumn, was negatively correlated with population density $(r=-0.975, t=6.205, p<0.025)$, and rapidly declined from 65.3 fawns per 100 females in 1981 to 6.8 in 1984 (Fig. 8). We found no evidence of pregnancy in any of the 17 undecomposed adult females $(>2.5$-years-old) which died in the winter of $1983-84$. In addition, of 33 2.5-year-old and older females relocated to another deer park in the spring of 1984, only one female produced off-spring in late July; but her fawn died shortly after birth (Wako, pers. comm.).

\section{Table 5}

Ages of female sika deer with their fawns. Figures in parentheses show the number of females observed.

\begin{tabular}{|c|c|c|c|c|}
\hline \multirow[t]{2}{*}{$\begin{array}{l}\text { Age } \\
\text { (years) }\end{array}$} & \multicolumn{4}{|c|}{ No. of females with fawn } \\
\hline & 1982 & 1983 & 1984 & Total \\
\hline 1.5 & $0 .(7)$ & & 0 (1) & $\begin{array}{ll}0 & \text { (8) }\end{array}$ \\
\hline 2.5 & 0 (3) & $\begin{array}{ll}0 & (8)\end{array}$ & & 0 (11) \\
\hline $\begin{array}{r}3.5 \\
>45\end{array}$ & 0 (1) & $2 \quad(4)$ & 1 (2) & $3 \quad(7)$ \\
\hline$\geqslant 4.5$ & $3(7)$ & 5 (11) & $1(9)$ & 9 (27) \\
\hline
\end{tabular}

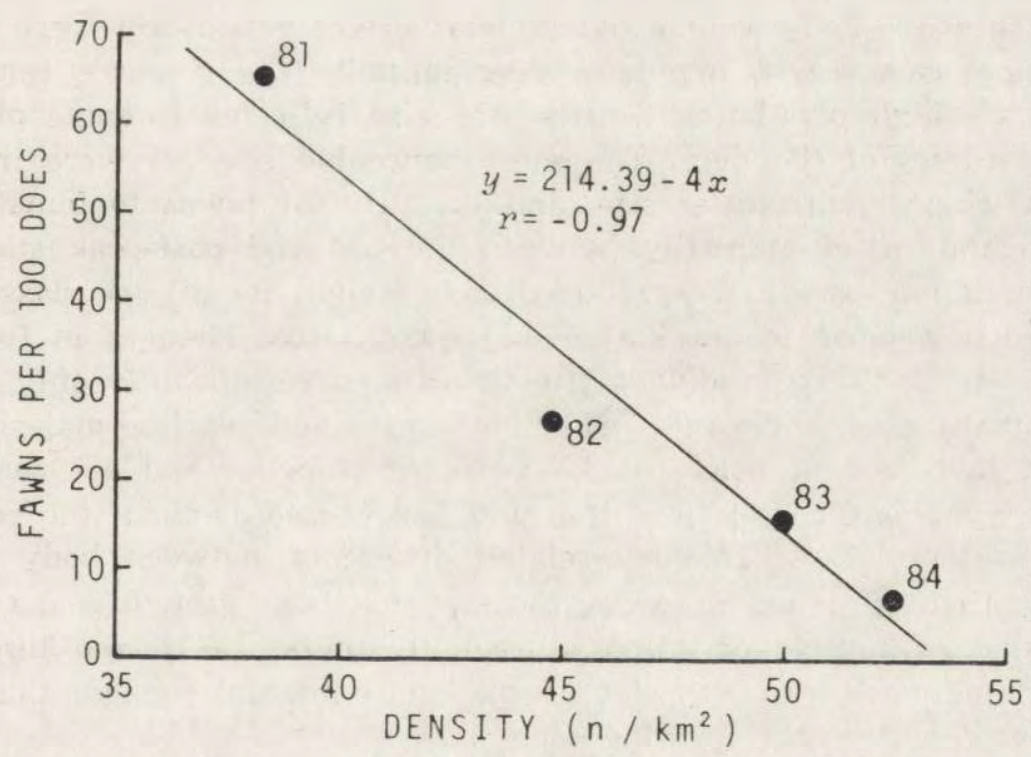

Fig. 8. Relationship between the number of fawns per 100 females to population density. 


\section{DISCUSSION}

The sika deer population on Nakanoshima Island increased rapidly to a peak of 53 animals $/ \mathrm{km}^{2}$ in the autumn of 1983 and markedly declined the following winter, due to both natural mortality $(22 \%)$ and removal $(32 \%)$. The shortage of summer forages was caused by the heavy grazing and the great concentration of deer on open pasture during the summer and autumn of 1983. Dwarf bamboo, which was the most important food in winter, had been completely eliminated in the winter of 1982-83 (Table 2). In the winter of $1983-84$, although the snow accumulation and mean temperature were similar to those of previous winters, the duration of snow cover of more than $30 \mathrm{~cm}$ in depth was 87 days, 30 days longer than the average of the winters of $1980-83$. Thus, with these restricted summer and winter food resources, the most acute situation occurred that winter. Maruyama \& Takano (1985) reported that in the winter of $1983-84$, when unusual heavy snow accumulated, most $(87 \%)$ of the winter-starved sika deer $\left(n_{4}=50\right)$, had depleted fat reserves below $25 \%$ of FMF in Omote-Nikko. Therefore, the low fat content in the femur (a mean of $13 \%$ of $\mathrm{FMF}, n=14$ ) suggests that starvation was the main cause of death of sika deer on Nakanoshima Island during this period. A mass mortality of sika deer was also recorded on Kinkazan Island (Suzuki \& Takatsuki, 1986) in Honshu during extreme weather conditions of the same winter.

Although the body weight and skeletal size of island deer were almost the same as those of mainland deer initially, the resource limitation caused by high population density was also reflected in some physical characteristics of the deer. The most noticeable changes were in body weight, chest girth, antler size, and the ratio of fawns to females, all of which declined markedly between the pre and post-peak stages of the population growth. The reduced body weight for all age classes was apparently related to qualitative and quantitative changes in food resources. In contrast, hind foot growth differed significantly only among the immature age classes (fawns of both sexes and yearling males). Body weight increased at least till 3.5 years for females and 4.5 years for males, whereas the growth of the hind foot ceased at about the yearling stage in both sexes. This age-related difference between body weight and skeletal size is explained by the fact that bone growth peaks earlier than that of muscle or adipose tissue (Reimers, 1972), and hind foot length fluctuates less with short term environmental changes than does body weight, except in growing deer.

Sexual dimorphism in body weight, chest girth, and hind foot length became apparent at 1.5 years of age in 1982, just before the population 
peaked. Feldhamer et al. (1984) found that sexual dimorphism in most body measurements of sika deer in Maryland was evident by 1.5 years of age. However, size differences between the sexes of sika deer on Nakanoshima Island did not occur until after 2.5 years of age in 1984, after peak density, because the magnitude of changes in measurements was larger in males than in females. For example, males one year or older lost nearly twice as much of their body weight as females between the pre and post-peak stages. Similar differences in the magnitude of changes between the sexes was also found in the jaw length in immature age classes. A possible explanation of this phenomenon is that the reduction of food had a greater effect in males than females because of the males larger growth coefficients and their longer period of growth (Feldhamer et al., 1984).

Other studies of cervids have also documented that the growth rate of males was more adversely affected by food shortage than that of females in species like the red deer (Cervus elaphus) (Clutton-Brock et al., 1982), reindeer (Rangifer tarandus) (Reimers, 1972; Leader-Williams \& Ricketts, 1982), white-tailed deer (Ullrey et al., 1967), and mule deer (Odocoileus hemionus hemionus) (Julander et al., 1961).

Age-related antler characteristics of the island deer in the early stage of their population increase would have been similar to the general pattern given for mainland deer, except that the island deer antlers were smaller. The smaller antler size of the island deer may be attributable to the individual characteristics of the one male originally introduced in 1957, resulting in the founder effect. The reduction of antler size was associated with the decline in body weight (Fig. 7). This suggests that food reduction also affected antler growth. Goss (1983) cited many papers demonstrating that antler growth was profoundly influenced by nutritional factors in several cervids. Antler length and mass, and therefore the number of points, is smaller in poorly nourished deer. Studies in Southern Poland showed an increase $(20 \%)$ of antler weight in roe deer (Capreolus capreolus) after the free living population obtained access to better food resources (Bobek, 1984).

The fertility of red deer has been related to body weight in females in summer both in captivity (Hamilton \& Blaxter, 1980) and in the wild (Bobek \& Kosobucka, 1985). In 1981, there was no evidence of low postnatal fawn production in the deer on Nakanoshima Island. The 1981 postpartum productivity of 65 fawn per 100 females one year or olden $(n=26)$ was comparable to the pregnancy rate of hunted sika deer from Tanzawa Mt. $(51.4 \% ; n=313)$ and Goyo Mt. $(70 \% ; n=30)$ in Honshu, as reported by Iimura (1980). Only after the population reached a density of 38 animals $/ \mathrm{km}^{2}$ in 1981 , did the production begin to show a noticeable 
decline. With good range conditions, sika deer have been known to conceive during their second year of life and have their first fawns when they are 2-years-old (Bennetsen, 1977; Iimura, 1980). In this study, one 1.5-year-old female was pregnant in 1982. However, no 2.5-year-old females with fawns were observed in autumn between 1982 and 1984 (Table 5). Therefore, it appears that at high densities, the decrease in summer range quality has a marked influence on fertility in yearlings and even in adults, which reflects on postpartum productivity. In addition, the frequency of the rutting call, which probably played a role in rutting activities in males, was extremely low in the autumn of 1983 (Kaji et $c l$., unpublished). The poor condition of males at that time probably affected the 1984 productivity.

Since, for many ungulates, the effects of resource limitation during winter have been shown to affect nutritional conditions of the growing fetus (Skogland, 1983), an increasing winter weight loss in female sika deer that comes with high density, seems to greatly affect neonatal size, indicated by hind foot length (Fig. 4) and jaw length (Fig. 5), which become shorter as density increases.

In cervids, since both the calving date and neonatal size are related to maternal size (Blaxter \& Hamilton, 1980; Skogland, 1983), small females tend to produce relatively small calves with a delayed calving time, which results in a shorter period of growth. Consequently, initial growth retardation has permanent effects, and may result in a size difference in all age classes (Suttie, 1980; Skogland, 1983). However, unlike body weight, no such evidence of changes in skeletal size (jaw length and hind foot length) in adults was found in the present study. This is reasonable, since all adult deer were born before the end of 1979 , when food quality and quantity was rich, the deer grew up well nourished.

Deterrent growth is usually associated with high population density in mammals (Scheffer, 1955). Among the Cervidae, the following factors are commonly associated with intraspecific differences in size: food quality and quantity (Klein, 1964, 1968, 1970; Reimers, 1972; Wegge, 1975; Verme \& Ozoga, 1980; Suttie, 1980; Leader-Williams \& Ricketts, 1982; Skogland, 1983; Challies, 1985), population density (Scheffer, 1955), social pressure in territorial species (Klein \& Strangaard, 1972), and densitydependent physiological stress (Christian et al., 1960). Christian et al. (1960) proposed that physiological stress involving adrenal cortical hyperplasia was the major factor that limits both the physical condition and the number of sika deer, e.g., mass $(60 \%)$ mortality at a density of 2.5 animals/ha on an island in Maryland one winter. They noted that the body size of the animals decreased in spite of the good nutritional conditions between pre-peak and peak stages of the population increase. 
However, Seal et al. (1983) showed that there were no significant differences in the absolute adrenal weight from the data of Christian et al. (1960). They also demonstrated that there was no evidence of a simple density depedent increase in adrenal corticosteroid secretory activity in healthy, well-fed white-tailed deer from a rapidly increasing population up to densities of 63 animals $/ \mathrm{km}^{2}$. Although the physical characteristics of sika deer on Nakanoshima Island changed in a density-dependent manner, food resources seem to be the most causal factor behind density-dependence. Therefore, it appears that the high mortality of deer in 1984 on Nakanoshima Island was caused by malnutrition and particularly severe winter conditions. The same factors were said to account for the population regulation mechanism of reindeer on St. Matthew Island (Klein, 1968).

In conclusion, our data suggests that a food shortage resulting from high population density and fluctuating climatic conditions was the main factor that determined both the size of the individual deer and the population.

Acknowledgements: Many people have helped us with this research over the years. We are grateful to the Muroran Forest District Office and the Hakodate Regional Forest Branch-Office for the permission to study on Nakanoshima Island and to the Nature preservation division of the Hokkaido Government for permission to capture the deer. To numerous students from the Brown Bear Research Group, Department of Forestry. Institute of Applied Zoology, Faculty of Veterinary Medicine (Hokkaido University), and Laboratory of Animal Management (The College of Dairying) who assisted us in gathering data in the field, we give our heartfelt thanks. We would also like to thank Drs, the late K. Muto, K. Ota, H. Mori, T. Igarashi, S. Higashi, Y. Maede, T. Kurohagi, the late R. Shibakusa, K. Ishigaki, M. Yoneda, S. Kondo, T. Yajima, Messrs. S. Kobayashi and A. Shimada, Miss M. Koyama for their encouragement and help. Drs. B. Bobek, H. Abe, and T. Saitoh for carefully reading the manuscript and giving useful advice, and $\mathrm{Mr}$. $\mathrm{N}$. Hachiya and Miss J. Terazaki for their skillful technical assistance. We are also indebted to the residents of Abut Cho, the staff of Toya-Ko Kisen Co., Inc., and Toya Limnological Station, Hokkaido University, for their supports during our stay on the island. In particular we would like to thank Messrs M. Okamura, T. Matsuda. H. Haruna, H. Asakura, and T. Nishi. This study was funded by a grant from the Nature Conservation Department, Environmental Agency, Japan, and in part by the Hokkaido Shimbun.

\section{REFERENCES}

1. Bennetsen E., 1977: Some facts about sika deer in Denmark. Deer, 4: 153-157.

2. Blaxter K. L. \& Hamilton W. J., 1980: Reproduction in farmed red deer, 2. Calf growth and mortality. J. Agric. Sci., 95: 275-284.

3. Bobek B., 1984: Management of a roe deer population on a deciduous forest in Southern Poland. Acta Zool. Fennica, 172: 241-242.

4. Bobek B. \& Kosobucka M., 1985: Modelling of the population dynamics and structure in red deer (Cervus elaphus L.) in Southern Poland. Proc. XVIIth Congr. Int. Game Biol: : 173-180.

5. Challies C. N., 1985: Establishment, control, and commercial exploitation of 
wild deer in New Zealand. [In: "Biology of deer production", Eds. Fennessy P. F., \& Drew K. R.] The Royal Society of New Zealand, Bull., 22: 23-36.

6. Christian J. J., Flyger V., \& Davis D. E., 1960: Factors in the mass mortality of a herd of sika deer, Cervus nippon. Chesapeak Sci., 1: 79-95.

7. Clutton-Brock T. H., Guiness F. E. \& Albon S. D., 1982: Red deer- Behavior and Ecology of Two Sexes. Univ. Chicago Press: 1-378. Chicago.

8. Feldhamer G. A., Stauffer J. R. Jr. \& Chapman J. A., 1984: Body morphology and weight relationships of Sika deer in Maryland. Z. Saugetierk., 50: 88-106.

9. Goss R. J., 1983: Deer Antlers- Regeneration, Function, and Evolution. Academic Press: $1-316$. London - N.Y.

10. Hamilton W. J. \& Blaxter K. L., 1980: Reproduction in farmed red deer. 1. Hind and stag fertility. J. Agric. Sci., 95: 261-273.

11. Iimura T., 1980: An ecological study on the Japanese deer, Cervus nippon centralis, in the Tanzawa Mountains from the viewpoint of forest protection. Dai Nippon Sanrinkai: 1-154 [In Japanese with English summary]. Tokyo.

12. Julander O., Robinette W. L. \& Jones D. A., 1961: Relation of summer range condition to male deer herd productivity. J. Wildl. Manage., 25: 54-60.

13. Kaji K., 1981: Range use of sika deer (Cervus nippon yesoensis Heude) in the Nemuroshibetsu district, Hokkaido. J. Mamm. Soc. Japan, 8: 226-362 [in Japanese with English summary|.

14. Kaji K., Ohtaishi N. \& Koizumi T., 1984: Population growth and its effect upon the forest used by Sika deer on Nakanoshima Island in Lake Toya, Hokkaido. Acta Zool. Fenica, 172: 203-205.

15. Klein D. R., 1964: Range-related differences in growth of deer reflected in skeletal ratios. J. Mammal., 45: 226-235.

16. Klein D. R., 1968: The introduction, increase, and crash of reindeer on St. Matthew island. J. Wildl. Manage., 32: 350-367.

17. Klein D. R., 1970: Food selection by North American deer and their response to over-utilization of preferred plant species. [In: "Animal populations in relation to their food resources", Ed. Watson A.] Brit. Ecol. Sci. Symp. 10. Blackwell Sci. Publ.: 25-46. Oxford.

18. Klein D. R., \& Strandgaard H., 1972: Factors affecting growth and body size of roe deer. J. Wildl. Manage., 36: 64-69.

19. Koike H. \& Ohtaishi N., 1985: Prehistoric hunting pressure estimated by the age composition of excavated sika deer (Cervus nippon) using the annual layer of tooth cement. J. Archaeol. Sci., 12: 443-456.

20. Kudo N. \& Ohtaishi N., 1977: Biometry of the yeso sika deer. J. Mamm. Soc. Japan, 7: 86.

21. Leader-Williams N. \& Ricketts C., 1982: Growth and condition of three introduced reindeer herds on South Georgia: the effects of diet and density. Holarctic Ecol., 5: 381-388.

22. Maruyama N., 1985: Evaluating nutritive condition of sika deer. [In: "Dynamics of Larger Mammals (Bear and Deer) and Natural Environment in Japanese Forest." Ed. Nature Conservation Dept., Environmental Agency, Japan].: 257-260 [In Japanese].

23. Maruyama N. \& Takano K., 1985: Effects of the heavy winter snowfall of 1984 on sika deer, ibid.: 248-253 [In Japanese].

24. Maruyama N. \& Totake Y., \& Katai N., 1975: Seasonal change of food habits sika deer in Omote-Nikko. J. Mamm. Soc. Japan, 6: 152-162 [In Japanese with English summary].

25. Miura S., Tani M., Sirao Y., Ooshio S., Kasai N., Matsumoto T. \& Mukaida A., 
1980: Correlation between body weight and antler length of sika deer bucks. J. Mamm. Soc. Japan, 8: 78.

26. Neiland K. A., 1970: Weight of dried marrow as indicator of fat in caribou femurs. J. Wildl, Manage., 34: $904-907$.

27. Ohtaishi N., 1976: Developmental variation of the antlers in Japanese deer at Nara Park (Preliminary). Ann. Rep. Nara Deer Res. Assoc., 3: 107-128 [In Japanese with English summary].

28. Ohtaishi N., 1980: Determination of sex, age, and death season of recovered remains of sika deer (Cervus nippon) by jaw and tooth-cement. Kokogaku to Sizenkagaku (Archaeology and Natural Sciences), 13: 51-73 [In Japanese with English summary].

29. Ranson A. B., 1965: Kidney and marrow fat as indicators of white-tailed deer condition. J. Wildl. Manage., 29: 397-398.

30. Reimers E., 1972: Growth in domestic and wild reindeer in Norway. J. Wildl. Manage., 36: $612-619$.

31. Riney T., 1955: Evaluating condition of free-ranging red deer (Cervus elaphus), with special reference to New Zealand. J. Sci. \& Tech., Sect. B., 36: 429-463.

32. Scheffer V. B., 1955: Body size with relation to population density in mammals. J. Mammal., 36: 493-515.

33. Seal U. S., Verme L. J., Ozoga J. J. \& Plotka E. D., 1983: Metabolic and endocrine responses of white-tailed deer to increasing population density. J. Wildl. Manage., 47: 451-462.

34. Skogland T., 1983: The effects of density dependent resource limitation on size of wild rein deer. Oecologia, $60: 156-168$.

35. Suttie J, M., 1980: Influence of nutrition on growth and sexual maturation of captive red deer stags. [In: "Reindeer/Caribou Symp. II Norway 1979" Eds. Reimers E., Gaare E. \& Skjenneberg S.]: $341-349$.

36. Suzuki K. \& Takatsuki S., 1986: Mass mortality of Sika deer on Kinkazan Island in 1984. Honurui kagaku (Mammalian Science), 53: 33-37 [In Japanese].

37. Takatsuki S., 1983: The importance of Sasa nipponica as a forage for sika deer (Cervus nippon) in Omote-Nikko. Jap. J. Ecol., 33: 17-25.

38. Takatsuki S., 1986: Food habits of Sika deer on Mt. Goyo, northern Honshu. Ecol. Res. 1: 119-128.

39. Ullrey D. E., Youatt W. G., Johnson H. E., Fay L. D. \& Bradley B. L., 1967: Protein requirement of white-tailed deer fawns. J. Wildl. Manage., 31: 679-685.

40. Verme L. J. \& Ozoga J. J., 1980: Effect of diet on growth and lipogenesis in deer fawns. J: Wildl. Manage., 44: 315-324.

41. Wegge P., 1975: Reproduction and early calf mortality in Norwegian red deer. J. Wildl. Manage., 39: 92-100.

Received 15 July 1987, Accepted 10 November 1987. 
Koichi KAJI, Toru KOIZUMI i Noriyuki OHTAISHI

\author{
WPLYW OGRANICZENIA ZASOBÓW POKARMOWYCH NA FIZYCZNA \\ I ROZRODCZA KONDYCJE JELENI SIKA NA WYSPIE NAKANOSHIMA, \\ HOKKAIDO
}

\title{
Streszczenie
}

W latach 1980 - 84 badano kondycję fizyczną i rozród jeleni sika Cervus nippon yesoensis Heude, 1884 introdukowanych na wyspę Nakanoshima $\left(5,2 \mathrm{~km}^{2}\right)$. Zagęszczenie populacji rosło od 31,5 osob. $/ \mathrm{km}^{2}$ w 1980 do 57,5 osob. $/ \mathrm{km}^{2}$ jesienią 1983 roku, a następnie zmalało w ciągu zimy $1983 / 84$ do 26,3 osob. $/ \mathrm{km}^{2} \mathrm{z}$ powodu naturalnej śmiertelności $(22 \%)$ i odstrzałów $(32 \%)$.

Wzrost liczebności populacji powodował gwaltowne ograniczanie zasobów pokarmowych. Do roku 1983 jelenie całkowicie wyjadły bambus (Sasa senanensis i S. kurilensis), który stanowił ich główny pokarm i zmuszone były do żywienia się korą i niejadalnymi roślinami. Zimą 1983/84 pokrywa śniegu zalegała dłużej niż zwykle, co spowodowało masowe upadki z głodu $(22 \%)$.

W początkowym okresie badań masa ciała i wielkość jeleni sika z wyspy nie różniły się od populacji na lądzie, natomiast w roku 1984 zwierzęta z wyspy były istotnie mniejsze i miały słabsze poroża. Proporcja liczby cieląt do samic w wieku 1 roku i starszych zmalała z $65 \%$ w 1980 do $7 \%$ w 1984 roku. Ograniczenie zasobów pokarmowych spowodowane wysokim zagęszczeniem populacji oraz zmienność warunków klimatycznych były głównymi czynnikami określającymi liczebność populacji i wielkość osobnika.

\section{EXPLANATION OF PLATE XV}

Changes in vegetation on the open pasture at the central part of Nakanoshima Island at an interval of two years. Summer photos in 1980 (upper) and 1982 (lower). All tall plants were eliminated except ragwort. 


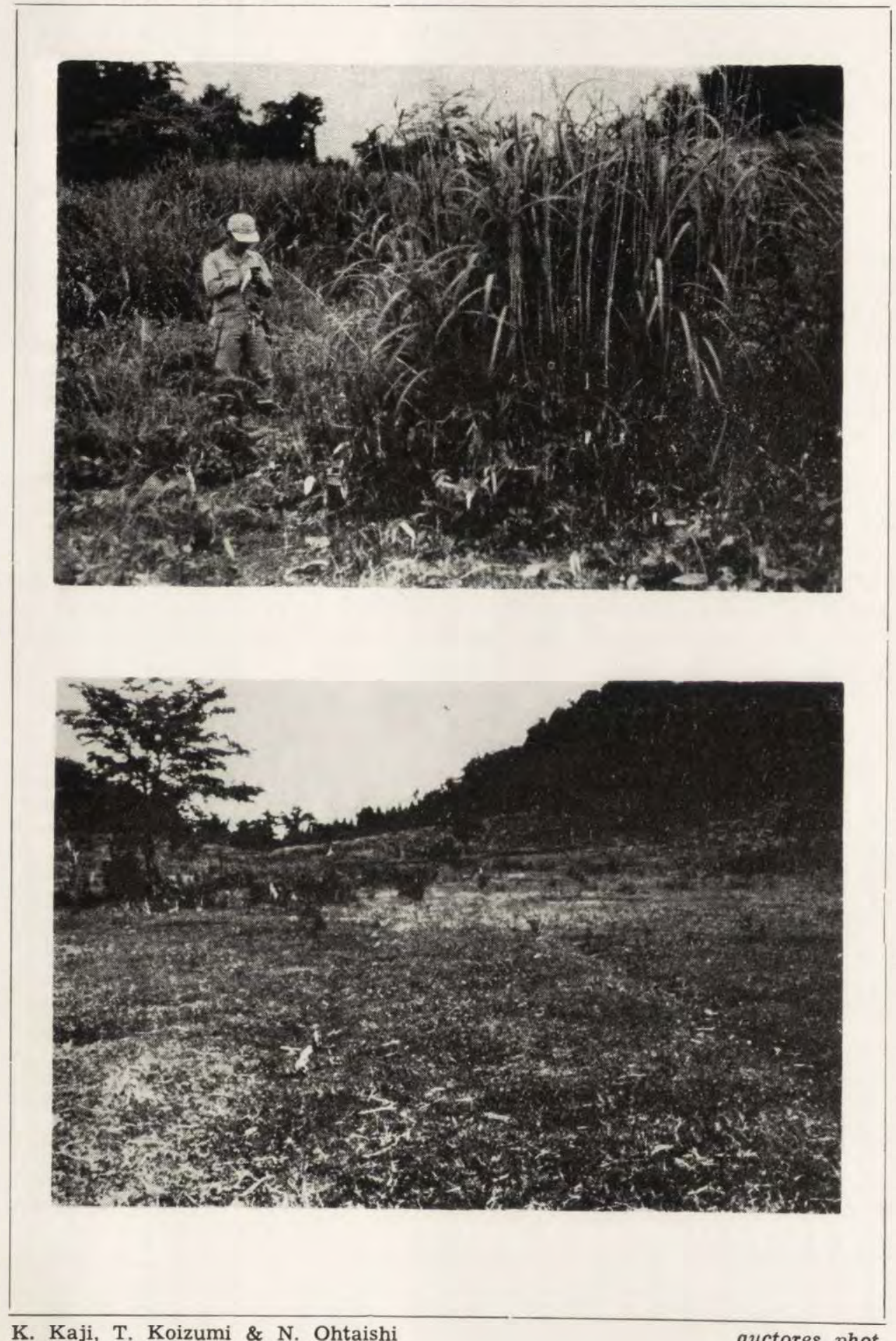

K. Kaji, T. Koizumi \& N. Ohtaishi 